\title{
Bacteriophage Delivery Systems Based on Composite PolyHIPE/Nanocellulose Hydrogel Particles
}

\author{
Tilen Kopač ${ }^{1}$, Ana Lisac ${ }^{1}$, Rok Mravljak ${ }^{1}$, Aleš Ručigaj ${ }^{1}$, Matjaž Krajnc ${ }^{1}$ (D) and Aleš Podgornik ${ }^{1,2, *}$ \\ 1 Department of Chemical Engineering and Technical Safety, Faculty for Chemistry and Chemical Technology, \\ University of Ljubljana, SI-1000 Ljubljana, Slovenia; tilen.kopac@fkkt.uni-lj.si (T.K.); \\ ana.lisac@fkkt.uni-lj.si (A.L.); rok.mravljak@fkkt.uni-lj.si (R.M.); Ales.Rucigaj@fkkt.uni-lj.si (A.R.); \\ matjaz.krajnc@fkkt.uni-lj.si (M.K.) \\ 2 COBIK, Tovarniška 26, SI-5270 Ajdovščina, Slovenia \\ * Correspondence: ales.podgornik@fkkt.uni-lj.si
}

Citation: Kopač, T.; Lisac, A.; Mravljak, R.; Ručigaj, A.; Krajnc, M.; Podgornik, A. Bacteriophage Delivery Systems Based on Composite PolyHIPE/ Nanocellulose Hydrogel Particles. Polymers 2021, 13, 2648. https:// doi.org/10.3390/polym13162648

Academic Editors: Irena Pulko and Constantinos Tsitsilianis

Received: 13 July 2021

Accepted: 7 August 2021

Published: 9 August 2021

Publisher's Note: MDPI stays neutral with regard to jurisdictional claims in published maps and institutional affiliations.

Copyright: (c) 2021 by the authors. Licensee MDPI, Basel, Switzerland. This article is an open access article distributed under the terms and conditions of the Creative Commons Attribution (CC BY) license (https:// creativecommons.org/licenses/by/ $4.0 /)$.

\begin{abstract}
The role of bacteriophage therapy in medicine has recently regained an important place. Oral phage delivery for gastrointestinal treatment, transport through the stomach, and fast release in the duodenum is one of such applications. In this work, an efficient polyHIPE/hydrogel system for targeted delivery of bacteriophages with rapid release at the target site is presented. T7 bacteriophages were encapsulated in low crosslinked anionic nanocellulose-based hydrogels, which successfully protected phages at $\mathrm{pH}<3.9$ (stomach) and completely lost the hydrogel network at a $\mathrm{pH}$ above 3.9 (duodenum), allowing their release. Hydrogels with entrapped phages were crosslinked within highly porous spherical polyHIPE particles with an average diameter of $24 \mu \mathrm{m}$. PolyHIPE scaffold protects the hydrogels from mechanical stimuli during transport, preventing the collapse of the hydrogel structure and the unwanted phage release. On the other hand, small particle size, due to the large surface-to-volume ratio, enables rapid release at the target site. As a consequence, a fast zero-order release was achieved, providing improved patient compliance and reduced frequency of drug administration. The proposed system therefore exhibits significant potential for a targeted drug delivery in medicine and pharmacy.
\end{abstract}

Keywords: TEMPO nanocellulose; T7 bacteriophage; encapsulation; drug diffusion; zero-order release

\section{Introduction}

In recent years, the spread of antibiotic-resistant bacteria became a global health problem making potential alternatives like bacteriophages an important field of study [1] Bacteriophages are natural killers of bacteria, which lyse bacteria to produce new progeny viruses [2]. Phage therapy is intriguing since phage self-replication ability leads to a local increase in their concentration, and the narrow host specificity of phages ensures the lack of broad off-target effects [3-6]. The success of phage therapy depends on bacterial physiological state and phage stability, survival, and consistent phage titer (concentration) for a stable dosage delivered at the site of infection [7,8]. Oral administration of phages is the least invasive and an easy to handle technique, however, there are some drawbacks since there is a possibility of phage inactivation when passing subsequent gut sections due to the acidic and proteolytic environment of the stomach [9]. Several studies have demonstrated that low $\mathrm{pH}$ can affect and inactivate phage populations $[10,11]$. Phage T7 used in our experiments remains stable at $\mathrm{pH} 6-8$ and is completely inactivated at $\mathrm{pH}$ below 3 [12]. To improve phage stability, encapsulation can be employed to increase the retention time of phages, to contain phage concentration at a therapeutically effective level, and to control the time of release [7] but also its stability. For gastrointestinal infections, phages were mostly encapsulated in liposomes $[13,14]$, and for other infections such as burn wounds, biofilms on implants, and root canal infections, phages were encapsulated in micropar- 
ticles $(\mathrm{d}=8.0 \pm 4.5 \mu \mathrm{m})$ [15], scaffolds [16], and hydrogels [17-19], in materials such as biopolymers [20], synthetic and semisynthetic polymers, and inorganic materials [16,21].

One of the rather novel biopolymers with several important properties is nanocellulose [22]. Especially, biopolymer-based hydrogels synthesized with 2,2,6,6-tetramethylpiperidine-1-oxyl (TEMPO)-oxidized cellulose nanofiber (TOCNF) have a great application prospect in medicine and pharmacy as well, especially in drug delivery systems [23-26]. TOCNF is a relatively new material in this field and could play a major role in future research due to its excellent properties, such as mechanical and chemical stability, non-toxicity, renewability, biodegradability, biocompatibility, and easy accessibility [27]. The best-known hydrogel synthesis is performed by ionic crosslinking with divalent ions, such as calcium(II) ions, which keeps the system non-toxic and suitable for medical and pharmaceutical use $[27,28]$. The mechanism of hydrogel formation is based on ionic interactions of the carboxyl functional groups present in the TOCNF with $\mathrm{pK}_{\mathrm{a}} 3.9[29,30]$. Their protonation causes hydrogel and pore shrinkage at $\mathrm{pH}<\mathrm{pK}_{\mathrm{a}}$ due to polymer chain attraction, while hydrogel and pore swelling is due to deprotonation at $\mathrm{pH}>\mathrm{pK}_{\mathrm{a}}$ due to polymer chain repulsion [30]. Moreover, unlike sodium alginate, the most commonly used biopolymer in drug delivery [31], TOCNF can be crosslinked without the addition of a crosslinking agent by hydrogen bond formation. Ageing of aqueous TOCNF dispersions at a concentration of 1-3 wt.\% can result in hydrogel structure over time. The ageing of TOCNF aqueous dispersions has already been studied in detail [32]. In this case, the biopolymer chains are crosslinked via hydrogen bonds. Secondly, as a result of carboxyl pendant groups on the surface, the TOCNF (anionic biopolymer) has a great possibility to be used for targeted drug delivery [30].

When hydrogels are used as a phage encapsulation system, their particle size is significant. While larger particles provide better protection from the acidic environment [33], smaller particles have shorter retention times through the gastrointestinal tract and faster release [34]. Therefore, it is important to tailor particle size according to the specific application. One possible approach is to introduce hydrogel in rigid, pre-synthesized, porous particles that can be highly diverse in their morphology, chemistry, and stability [35]. Among them, high internal phase emulsion polymer (polyHIPE) particles exhibiting high porosity, mechanical stability, diversity in size, and microstructure consisting of large void pores (VP) and smaller interconnecting pores (IP) connecting VP in all three dimensions [36]. As both the VP interconnectivity and porosity are high, this results in a highly permeable material capable of a high encapsulation capacity and minimal mass transport resistance. While polyHIPE morphology itself already has a good disposition due to the cage-like structure of the larger VP surrounded by smaller IP which can be independently tailored to match particular application [37], and excellent mechanical properties [38] assure robust and reliable performance. We therefore hypothesize that polyHIPE materials are suitable for protection and fast release of the encapsulated drug. Based on the chemistry of the chosen monomers, they can be easily functionalized [39]. High structural variability is achieved by a variety of preparation procedures such as continuous microfluidic photopolymerization [40,41] or via triple emulsion induced by dispersing HIPE inside a solution of a stabilizer causing polydisperse particle formation, which is then polymerized [42,43]. As such, they were already implemented for bone filling and cell delivery [44,45].

In this work, we prepared a polyHIPE-hydrogel composite material with encapsulated T7 bacteriophage for potential application in phage therapy. Immobilization efficiency and release were investigated in an acidic environment with $\mathrm{pH}$ such as to mimic conditions that are encountered in the stomach $(\mathrm{pH}=2)$ and duodenum $(\mathrm{pH}=5-7)$ [46] where release is preferred. Release of bacteriophage was studied under different preparation and $\mathrm{pH}$ conditions, demonstrating zero-order kinetics.

\section{Materials and Methods}

The experimental work includes the preparation of an efficient system for encapsulation of T7 bacteriophages in a release medium with a $\mathrm{pH}$ of 2 and activation of the 
release at the highest possible release rate in the medium at a $\mathrm{pH}$ of 5-7. Two crosslinking mechanisms were used to prepare $1.5 \%$ TOCNF hydrogels. First, ageing hydrogen bonding between polymer chains forming a hydrogel 3D structure (crosslinking without the addition of ionic or chemical crosslinkers) and second, ionic crosslinking with $\mathrm{Ca}^{2+}$ ions' addition of $15 \mathrm{mM}$ aqueous $\mathrm{CaCl}_{2}$ solution.

\subsection{Materials}

Nanocellulose hydrogel was prepared using 2,2,6,6-tetramethylpiperidine-1-oxyl (TEMPO)-oxidized cellulose nanofibers (TOCNF) with the chemical formula $\left[\left(\mathrm{C}_{6} \mathrm{H}_{10} \mathrm{O}_{5}\right)_{\mathrm{x}}\right.$ $\left.\left(\mathrm{C}_{6} \mathrm{H}_{9} \mathrm{O}_{4} \mathrm{COONa}\right)_{\mathrm{y}}\right]$ and the carboxylate level of $0.2-2 \mathrm{mmol} / \mathrm{g}$ solids that was purchased from The Process Development Centre, University of Maine (UMAINE PDC), USA. Calcium chloride was used as received from Merck (Darmstadt, Germany).

Sodium phosphate dibasic heptahydrate $\left(\mathrm{Na}_{2} \mathrm{HPO}_{4} \cdot 7 \mathrm{H}_{2} \mathrm{O}\right)$, sodium dihydrogen phosphate monohydrate $\left(\mathrm{NaH}_{2} \mathrm{PO}_{4} \cdot \mathrm{H}_{2} \mathrm{O}\right)$, sodium acetate $\left(\mathrm{CH}_{3} \mathrm{COONa}\right)$, sodium hydroxide ( $\mathrm{NaOH}$ pellets, an assay of $\geq 98 \%$ (acidimetric)) and hydrochloric acid ( $\mathrm{HCl}$, an assay of 36.5-38.0\%) were supplied by Sigma-Aldrich (St. Louis, MO, USA). Listed chemicals were used as received for preparation of phosphate $(\mathrm{pH}=7)$ and acetate $(\mathrm{pH}=5)$ buffer.

PolyHIPE particles were synthesized using poly(ethylene glycol)-block-poly(propylene glycol)-block-poly(ethylene glycol) or Synperonic ${ }^{\circledR}$ L 121 (PL121) and Synperonic ${ }^{\circledR}$ F 127 (PF127) (Sigma-Aldrich, St. Louis, MO, USA) as surfactants, glycidyl methacrylate (Sigma-Aldrich) (GMA), ethylene glycol dimethacrylate (Merck KGaA, Darmstadt, Germany) (EGDMA) as monomers, phenyl bis(2,4,6-trimethyl benzoyl)phosphine oxide (BASF Schweiz AG, Kaisten, Switzerland) (IC819) as photoinitiator, calcium chloride dihydrate (Honeywell Fluka, Charlotte, NC, USA) $\left(\mathrm{CaCl}_{2} \cdot 2 \mathrm{H}_{2} \mathrm{O}\right)$, and ethanol (Kefo, Ljubljana, Slovenia) $(\mathrm{EtOH})$. Deionized water was filtered through a $0.22 \mu \mathrm{m}$ filter before use.

Bacteriophages were produced with E. coli growing, and enumerated using Lysogeny Broth (LB) (LLG Labware, Meckenheim, Germany), agar (Sigma-Aldrich, St. Louis, MO, USA), and SM buffer (1 g gelatin (Sigma-Aldrich, St. Louis, MO, USA), $5.8 \mathrm{~g} \mathrm{NaCl}$ (Merck $\mathrm{KGaA}$, Darmstadt, Germany), $2 \mathrm{~g} \mathrm{MgSO}_{4} \cdot 7 \mathrm{H}_{2} \mathrm{O}$ (Merck KGaA, Darmstadt, Germany), $50 \mathrm{~mL} 1 \mathrm{M}$ Tris- $\mathrm{HCl}$ (pH 7.5) (Fisher Scientific F, Loughborough, UK), and deionized water to $1 \mathrm{~L}$ ).

\subsection{Bacteriophage and Bacterial Strains}

A lytic Podoviridae bacteriophage T7 (DSM 4623) and its host Escherichia coli K-12 MG1655 strain (DSM 18039) were used in all experiments (DSMZ Institute, Leibniz, Germany). High titer phage lysate was produced using well-established protocols recommended by DSMZ Institute, Germany. Bacterial cultures for phage titer determination were prepared in laboratory flasks in Lysogeny Broth (LB) $(\mathrm{pH} 7)$ and incubated at $37^{\circ} \mathrm{C}$ overnight [47].

\subsection{PolyHIPE Particle Preparation}

PolyHIPE particles were synthesized using a similar composition reported previously for polyHIPE monolith preparation [48]. To prepare $30 \mathrm{~mL}$ of HIPE, first, the organic phase was prepared in a tall $100 \mathrm{~mL}$ beaker consisting of $2.188 \mathrm{~g}$ GMA, $1.003 \mathrm{~g}$ EGDMA, $0.348 \mathrm{~g}$ PL121, and $0.016 \mathrm{~g}$ IC819. The aqueous phase was prepared separately with $26.231 \mathrm{~g}$ demi water, $0.262 \mathrm{~g} \mathrm{CaCl}_{2} \cdot 2 \mathrm{H}_{2} \mathrm{O}$, and $0.362 \mathrm{~g}$ PF127. The organic phase was then mixed at 8000 rpm (Ultra Turrax mixer, IKA T25, S25N-18G disperser, IKA, Germany), and the aqueous phase was slowly added at a flow rate of $2 \mathrm{~mL} / \mathrm{min}$. Initially, formed emulsion exhibited high viscosity, decreasing substantially with further addition of the aqueous phase resulting in fluid water-in-oil-in-water $(\mathrm{W} / \mathrm{O} / \mathrm{W})$ triple emulsion. The beaker containing emulsion was irradiated between two UV lights (light intensity $\approx 13 \mathrm{~mW} / \mathrm{cm}^{2}$, wavelength maximum at $365 \mathrm{~nm}$ ) for $1 \mathrm{~h}$, and then diluted with $20 \mathrm{vol} \% \mathrm{EtOH}$. Before, application particles were filtered through various mesh sizes to obtain particles ranging from $15-50 \mu \mathrm{m}$ and washed extensively with $20 \mathrm{vol} . \% \mathrm{EtOH}$. 


\subsection{PolyHIPE Particle Characterization}

Field-emission scanning electron microscope (FEG-SEM, JEOL JSM 7600 F, Jeol Inc., Tokyo, Japan) was used to observe the morphology and size of polyHIPE particles after synthesis. Furthermore, images were analyzed with ImageJ software to determine the polyHIPE particles interconnecting pore size and distribution. PolyHIPE particle size analysis after filtration was performed with an optical microscope (Zeiss Imager.Z2m, Carl Zeiss AG, Jena, Germany) in reflected light.

\subsection{Preparation of PolyHIPE/Hydrogel Particles with Encapsulated T7 Bacteriophage}

Particles containing hydrogel and bacteriophage were prepared in $10 \mathrm{~mL}$ of suspension containing polyHIPE particles and T7 bacteriophage at a concentration of $2 \mathrm{mg} / \mathrm{mL}$ and $1.85 \times 10^{9} \mathrm{PFU} / \mathrm{mL}$, respectively, in $10 \mathrm{mM}$ phosphate buffer $(\mathrm{pH}=7)$. The suspension was mixed overnight on a shaker to allow T7 bacteriophage diffusion into the polyHIPE particles. During the mixing, the $\mathrm{CaCl}_{2}$ acting as an ionic crosslinking agent was added to the dispersion at a final concentration of $15 \mathrm{mM}$. Afterward, dry TOCNF was added under constant stirring at $100 \mathrm{rpm}$ to achieve a dispersion concentration of $1.5 \%(w / v)$. The dispersion was then additionally stirred for $24 \mathrm{~h}$.

Particles without $\mathrm{CaCl}_{2}$ addition were also prepared using the same procedure, except that at the end, the dispersion was stirred for 7 days to allow hydrogel ageing and hydrogen bond formation [32].

The dispersion was filtered through filter paper (Macherey-Nagel 640 with pore size of 12-25 $\mu \mathrm{m}$ ). The filter cake with polyHIPE/hydrogel/bacteriophage particles was washed with $10 \mathrm{mM} \mathrm{HCl}$ solution to remove unreacted TOCNF from the particle surface. For better understanding of the paper, the polyHIPE/TOCNF particles' synthesis are illustrated in Scheme 1.

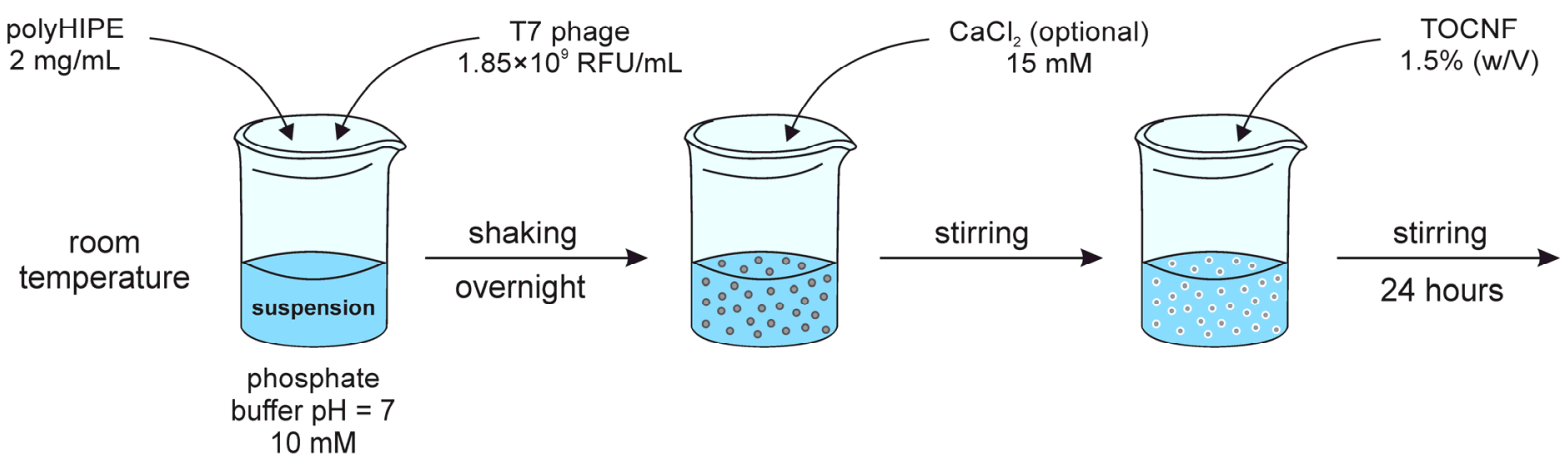

Scheme 1. The schematic representation of the polyHIPE/TOCNF synthesis, including the two crosslinking mechanisms of TOCNF hydrogels' preparation. The values represent the final concentration of the substance in the beaker.

\subsection{Phage Titer Determination}

Bacteriophage concentration (plaque-forming units; $\mathrm{PFU} \mathrm{mL}{ }^{-1}$ ) was determined by standard double agar overlay plaque assay [49]; $50 \mu \mathrm{L}$ of phage sample was transferred to Eppendorf tube containing $450 \mu \mathrm{L}$ SM buffer. The dilution series was made from each sample and $10 \mathrm{~mL}$ of each dilution in triplicates was dropped on double-layer LB agar plastic Petri dishes with $90 \mathrm{~mm}$ diameter; $5 \mathrm{~mL}$ of LB with $0.7 \%$ agar $(w / v)$ were mixed with $100 \mu \mathrm{L}$ of overnight bacterial culture and then poured on LB agar plate with $1.4 \%$ agar $(w / v)$ forming bacterial lawn. LB agar plates were incubated at $37^{\circ} \mathrm{C}$ overnight and plaques were enumerated after $6 \mathrm{~h}$. 


\subsection{Behavior of Phage Release from PolyHIPE/Hydrogel and the Determination of} Kinetics Parameters

A description of solute release behavior of the controlled release hydrogel was determined by Ritger and Peppas equation which relates the fractional drug release $\left(M_{t} / M_{0}\right)$ to the release time $(t)[50,51]$ :

$$
\frac{M_{t}}{M_{\infty}}=k t^{n}
$$

where $M_{\mathrm{t}}$ is mass of drug released until time $t, M_{\infty}$ is the amount of drug released when equilibrium is achieved, $k$ is a constant incorporating characteristics of the macromolecular network system and the drug, and $n$ is the diffusional exponent, which is indicative of the transport mechanism. The behavior of the controlled release from hydrogel (diffusional exponent $n$ ) and the drug release rate $(k)$ were obtained from the linear logarithm form of Equation (1):

$$
\ln \left(\frac{M_{t}}{M_{\infty}}\right)=\ln k+n \ln t
$$

where the values of $k$ and $n$ were obtained from the intercepts and gradients of the plots of $\ln \left(M_{\mathrm{t}} / M_{\infty}\right)$ versus $\ln (t)$.

\section{Results and Discussion}

\subsection{Synthesized PolyHIPE Particles}

To prepare the desired triple W/O/W emulsion HIPE, two nonionic surfactants namely PL121 and PF127 with hydrophilic-lipophilic balance (HLB) values of 1 and 22, respectively, were used [52]. Their ratio was found to be very important to obtain stable particles of required dimensions since compositions departing from the optimal ratio produced no particles. To accommodate as much as possible hydrogel and bacteriophages, mechanically stable polyHIPE particles with $90 \%$ porosity were prepared and further characterized. The density of the polymer particles was calculated to be $0.11 \mathrm{~g} / \mathrm{mL}$ using the porosity and bulk polymer density $(1.1 \mathrm{~g} / \mathrm{mL})$. Figure 1 shows particles exhibiting size distribution predominantly from 10 to $50 \mu \mathrm{m}$ with an average diameter of $24 \mu \mathrm{m}$ and $\mathrm{FWHM}=21 \mu \mathrm{m}$.

\subsection{Targeted Release of Bacteriophage T7 from 1.5\% TOCNF Hydrogel}

PolyHIPE/hydrogel/bacteriophage composite was prepared in two different ways. The first approach is rather intuitive using $\mathrm{Ca}^{2+}$ ions as a crosslinking agent causing ionic interactions and rapid hydrogel formation. The second one was based on differences in the shear force fields. While formation of the hydrogel 3D structure in the dispersion and on the surface of polyHIPE particles is restricted due to a constant stirring, this is not the case inside the polyHIPE particles where the liquid is stagnant, consequently allowing the formation of a hydrogel structure. The polyHIPE particles were therefore not only beneficial to define delivery system geometry but also enabled the preparation of composite without the addition of any crosslinking agent. In this case, the effect of ageing of TOCNF to form hydrogel structure was exploited [32]. To better understand the mechanical properties of TOCNF hydrogels, which play a pivotal role also in the case of bacteriophage delivery, rheological properties were studied in detail in our recent articles $[28,30]$. The average pore size of TOCNF hydrogels was determined based on oscillatory frequency sweep tests. The huge amount of hydrogel samples (different concentration of biopolymer and crosslinker) tested in [30] allowed to choose the most suitable TOCNF hydrogel composition for phage encapsulation and $\mathrm{pH}$ trigger release. 

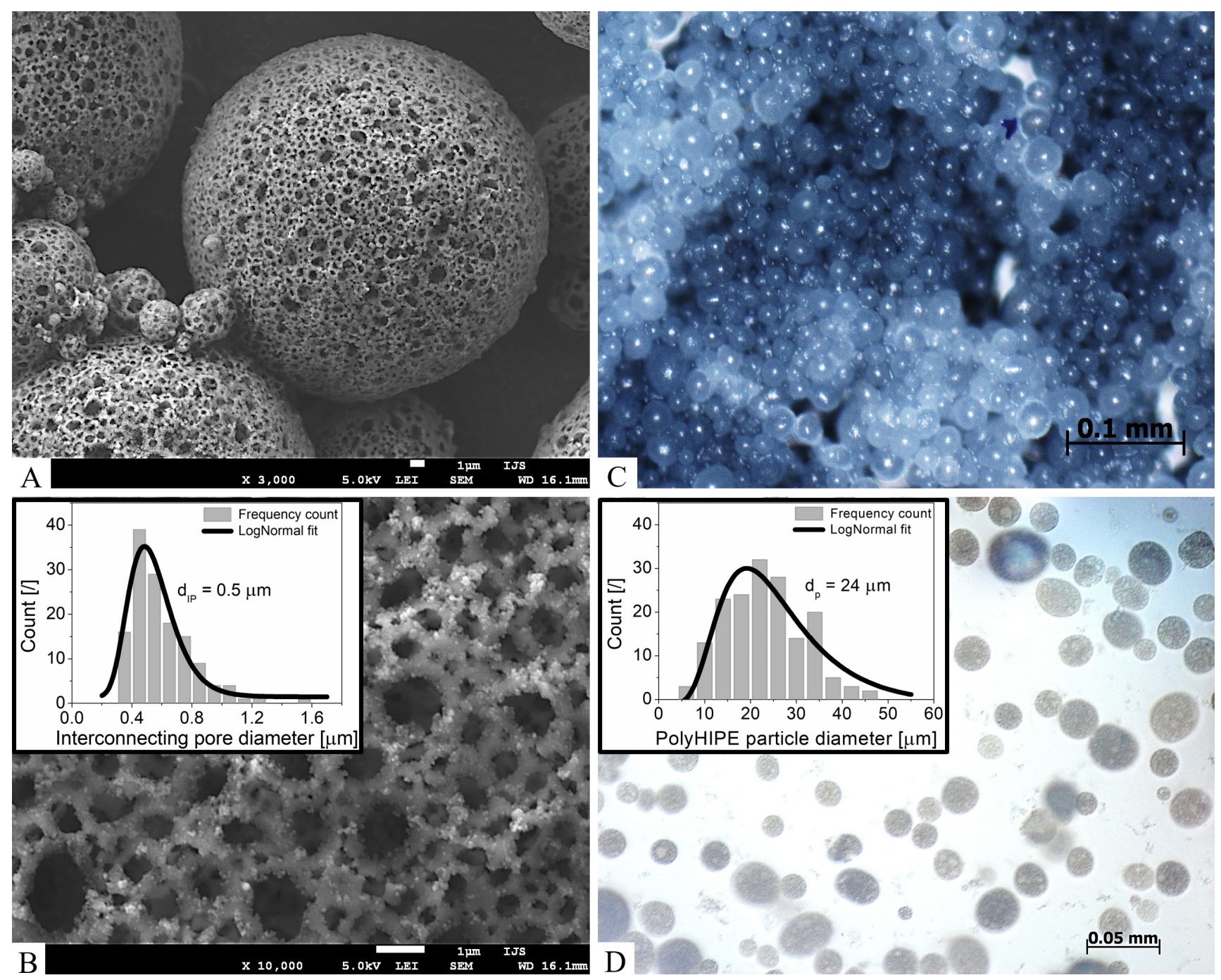

Figure 1. Microscope images of polyHIPE particles with corresponding IP and particle size distributions. On the left are: (A) SEM image at 3000 and (B) 10,000 $\times$ magnification used to obtain the IP distribution and mean IP size $\left(d_{I P}\right)$ shown in the inset in B panel. On the right, optical microscope images used to measure the particle size distribution and mean particle size $\left(d_{p}\right)$ taken after filtration in an aqueous solution with reflected $((\mathbf{C})$ image) and transmitted light $((\mathbf{D})$ image). Images were analyzed with ImageJ software, and median IP and particle size were obtained from the LogNormal distribution.

The release from both composites was investigated at $37^{\circ} \mathrm{C}$ by changing the $\mathrm{pH}$ of the release environment from 2 to 5 or 7 . Such conditions were chosen to simulate conditions present in the human body. Results in Figure 2 (inset) show that bacteriophages are not released from the hydrogel at $\mathrm{pH} 2$, irrespective of the crosslinking mechanism used to prepare the hydrogel. T7 bacteriophages have a hydrodynamic diameter of approximately $60 \mathrm{~nm}$ [53]. As shown in our previous work [30], the average pore size of $1.5 \%$ TOCNF hydrogel in a medium with $\mathrm{pH}<\mathrm{pK}_{\mathrm{a}}$ is $11.4 \mathrm{~nm}\left(0 \mathrm{mM} \mathrm{Ca}^{2+}\right)$ and $7.9 \mathrm{~nm}(15 \mathrm{mM}$ $\left.\mathrm{Ca}^{2+}\right)$. The smaller pore size in the hydrogel compared to the hydrodynamic radius of $\mathrm{T} 7$ encapsulates bacteriophages in the hydrogel without allowing diffusion. After $3 \mathrm{~h}$, which is the average time needed to empty the stomach by 50\% [54], the medium was changed to higher $\mathrm{pH}$ values ( $\mathrm{pH}$ of 5 or 7 ). Figure 2 shows the release of bacteriophages when the $\mathrm{pH}$ of the medium was changed which was in less than $30 \mathrm{~min}$. The release activated by the $\mathrm{pH}$ change above the substituent group $\mathrm{pK}_{\mathrm{a}}$ of TOCNF is enabled due to electrostatic repulsive forces between the negatively-charged polymer chains as a result of deprotonation, which caused movement of polymer chains and enlargement of the pores in the hydrogel network $[30,55]$. 

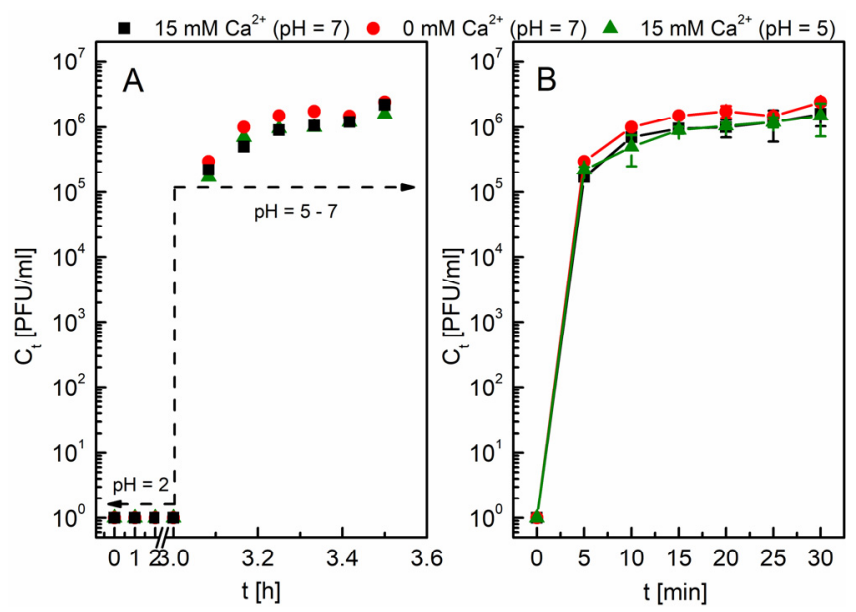

Figure 2. Bacteriophage release from $1.5 \%$ TOCNF hydrogel crosslinked in polyHIPE particles. The colors represent the concentration of the ionic crosslinking agent $\left(\mathrm{Ca}^{2+}\right)$ and the $\mathrm{pH}$ of the release medium. The A panel shows the total process of phage release for the first $3 \mathrm{~h}$ in medium with $\mathrm{pH} 2$ and afterward in medium with $\mathrm{pH} 5$ or 7 . The $\mathbf{B}$ panel illustrates only the release after $\mathrm{pH}$ switch (after 3 h).

A more detailed analysis of bacteriophage release from differently crosslinked samples is shown in Figure 3. The linear dependence of the released bacteriophage amount normalized to the total mass estimated from the mass balance as a function of time is demonstrated indicating a linear release. From the comparison of black and green lines, it can be concluded that release is independent of the $\mathrm{pH}$ value once it is higher than the $\mathrm{pK}_{\mathrm{a}}$ of the substituent groups. On the other hand, it can be observed that the release rate is a function of the crosslinking mechanism.

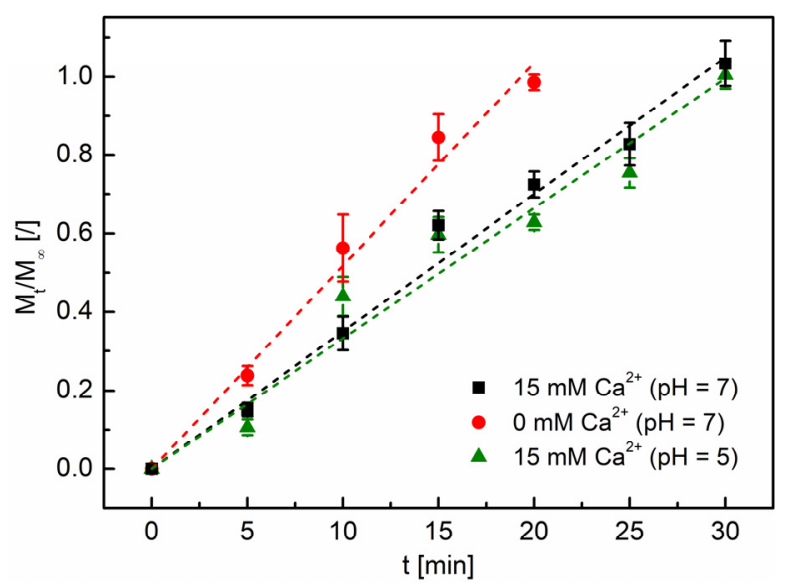

Figure 3. Normalized bacteriophage released at $37^{\circ} \mathrm{C}$ as a function of time. The colors represent the concentration of ionic crosslinking agent $\left(\mathrm{Ca}^{2+}\right)$ and the $\mathrm{pH}$ of the release medium.

The release is faster in a hydrogel without a crosslinking agent (Figure 3) [30]. Due to stronger repulsive electrostatic interactions in comparison to predominant hydrogen bond interactions between polymer chains $[30,32,56]$, the hydrogel prepared under ageing swells faster, resulting in larger pores in a shorter time interval than in the case of an ionically crosslinked hydrogel. In this case, ionic interactions are mainly involved in the crosslinking process along with hydrogen interactions [56]. A higher crosslinking density is achieved, which consequently induces smaller pores in the hydrogel [28]. Therefore, during deprotonation, the repulsive electrostatic interactions make it difficult to move polymer chains that are interconnected by stronger ionic interactions. On the other hand, a very low concentration of the ionic crosslinking agent $(15 \mathrm{mM})$ was used, so the differences 
in the bacteriophage release rate from the different crosslinked hydrogels are minimal (see Figure 2 and slope of the linear function in Figure 3).

\subsection{Kinetics Behavior, Mechanisms, and Order of Bacteriophage Release}

The release behavior of solutes from TOCNF system incorporated into polyHIPE was investigated by defining the release mechanism considering the assumption that bacteriophages do not interact with the hydrogel. As explained in Section 3.2., phage release did not occur at $\mathrm{pH} 2$ (Figure 2, inset) but it is triggered by $\mathrm{pH}$ increase. The release is present when the hydrogel pore size is sufficiently increased due to swelling allowing phage diffusion. Accordingly, one would also expect that due to a high polyHIPE porosity, the release is only a function of hydrogel mesh size and as such is controlled by a Fickian diffusion with a high velocity of phage from the matrix and low velocity of polymeric relaxation, similar to what was already shown for TOCNF hydrogels [28,30]. In contrast, the results presented in Figure 3 indicate zero-order release kinetics. This makes us conclude that the release mechanism cannot be described by a simple diffusion model and that a more complex description is required.

One possibility is using the semi-empirical Ritger and Peppas equation (Equation (1)) allowing discrimination between different transport mechanisms. The transport mechanism is determined with the diffusion exponent $n$ value, namely for spherical hydrogel particles: (i) $n=0.43$ (Fickian diffusion, where the diffusion is much greater than the process of polymer chain relaxation), (ii) $0.43<n<0.85$ (anomalous (non-Fickian) transport where the diffusion and relaxation rates of the polymer network are comparable), and (iii) $n=0.85$ (zero-order release, Case II where diffusion is very fast compared to the relaxation of the polymer network) [50,51]. An extreme example of (iii) is Super Case II $(n>0.85)$ which suggests that the velocity of solvent diffusion is much higher than the polymeric relaxation process, causing an acceleration of solvent penetration [51,57].

The results from Figure 3 were recalculated using Equation (2) and shown in Figure 4. Linear fit allowed determination of $k$ and $n$ shown in Table 1 . It has to be mentioned that $\mathrm{R}^{2}$ is satisfactory due to high relative standard deviation of counting method that limits accurate determination of bacteriophage concentration [58,59]. According to literature [50], the Equation (1) is valid for the first $60 \%$ of the fractional release. Furthermore, in Figure 4, the linear fit for $100 \%$ of the fractional release is evident. In all cases, $n$ value is above 1 , therefore the phage release can be classified as transport Super Case II, where the phage release mechanism is described as a consequence of swelling and macromolecular relaxation of the polymer chains limiting the typical diffusion process. Apparently, the porous polyHIPE matrix behaves as an obstacle to hydrogel relaxation and swelling. One can imagine that $\mathrm{OH}^{-}$ions penetrating from more basic release medium can freely enter the polyHIPE particle. Next, the repulsive forces cause the movement of the polymer chains, which allows water to diffuse into the hydrogel matrix [30]. In the case of a linear growth of the hydrogel system, the volume of the hydrogel increases to infinity, until the weaker hydrogen and ionic interactions can no longer maintain the 3D structure of the hydrogel [60], forming branched or forked chains with dimensions ranging from 20-50 nm in width and lengths up to several micrometers [32]. They start to concurrently diffuse with the phages into solution through polyHIPE pores of $2.8 \mu \mathrm{m}$, additionally affecting the rate of drug release.

The efficiency of the TOCNF-based hydrogel systems lies in the fast release rate followed by the $100 \%$ release of bacteriophages. Firstly, even though that phage diffusion is limited, the release time is highly favorable enabling complete release in $30 \mathrm{~min}$ due to the small dimensions and a very high surface area to hydrogel volume ratio of the polyHIPE particles. From the lower $k$ values for hydrogels prepared by ionic crosslinking, it can be concluded that they swell slightly slower with slower macromolecular relaxation compared to aged hydrogels. As follows, the release rate for systems without ionic crosslinking is slightly faster than in the ionically crosslinked hydrogels which can be concluded from the higher fitted value of $k$ (Table 1). Secondly, the complete bacteriophage release proves 
that the crosslinking of the hydrogel and the encapsulation of the bacteriophages did not affect the stability of phages in hydrogels, which is a potential problem with many other polymer-based hydrogels, but even protected them against low $\mathrm{pH}$ value deactivation [61]. Finally, complete dissolution of the hydrogel structure occurs, allowing $100 \%$ release of bacteriophages into the release environment, which can be seen after $30 \mathrm{~min}$ (Figure 2).

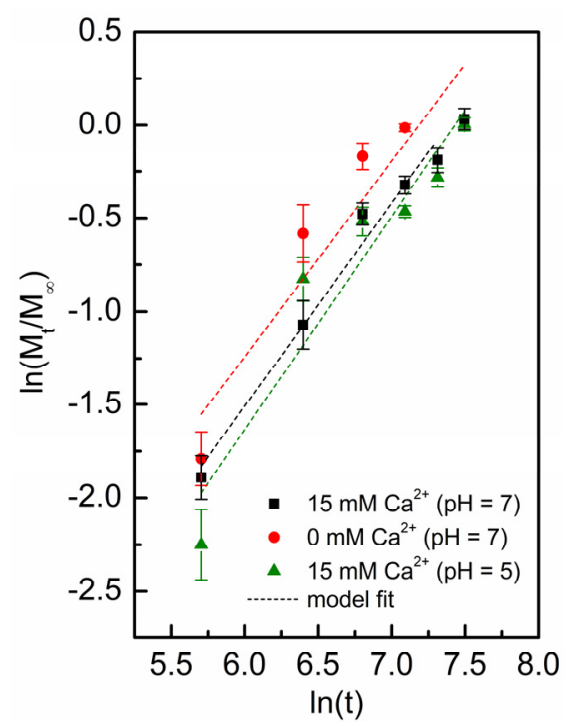

Figure 4. The amount of released bacteriophage $\left(M_{t} / M_{\infty}\right.$, see Equation (2)) from $1.5 \%$ TOCNF hydrogels prepared in polyHIPE particles with different concentrations of $\mathrm{Ca}^{2+}$ in release medium with a $\mathrm{pH}$ of 5 and 7 at $37^{\circ} \mathrm{C}$.

Table 1. Values of kinetics constant $k$, the diffusional exponent $n$ and goodness of linear fit $R^{2}$ obtained from Figure 4.

\begin{tabular}{cccccc}
\hline \multicolumn{2}{c}{ Sample Names } & & & & \\
\hline Biopolymer & Crosslinker $(\mathbf{m M})$ & $\mathbf{p H}$ & $\boldsymbol{k} \cdot \mathbf{1 0}^{\mathbf{4}}(\mathbf{s})$ & $\boldsymbol{n}$ & $\boldsymbol{R}^{\mathbf{2}}$ \\
\hline \multirow{3}{*}{$1.5 \%$ TOCNF } & 15 & 7 & 3.22 & 1.09 & 0.97 \\
& 0 & 7 & 5.42 & 1.04 & 0.87 \\
& 15 & 5 & 2.06 & 1.14 & 0.89 \\
\hline
\end{tabular}

The main purpose of this work was to show the benefits of combining microscopic porous particles with hydrogels for the encapsulation of T7 bacteriophages. We showed that protection against low $\mathrm{pH}$ can be achieved and that the targeted release rate is constant until all phages are released which takes only $30 \mathrm{~min}$. Furthermore, over $80 \%$ of phages were released in the first $5 \mathrm{~min}$ independently of the hydrogel preparation method. Taking also into consideration that ionically crosslinked TOCNF hydrogels have better mechanical and rheological properties, can be easily morphologically altered [28,30,32], and can be prepared faster compared to aged hydrogels, we think that they are more suitable for medical and pharmaceutical applications. Finally, a zero-order release was achieved which is, according to the applications of such delivery systems in pharmacy, the best way to control plasma concentration offering several advantages, including improved patient compliance and reduction in the frequency of drug administration [62].

\section{Conclusions}

In this work, new systems for targeted drug delivery were presented. PolyHIPE/TOCNF hydrogel systems for encapsulation of 77 bacteriophages and targeted delivery to the medium at pH 5-7 was prepared. Protection (encapsulation) of bacteriophages in TOCNF hydrogels allows transport through the stomach to the duodenum. TOCNF hydrogels 
proved to be an excellent encapsulation system due to their exceptional mechanical properties, as the bacteriophage infectivity did not decrease during crosslinking. Furthermore, polyHIPE particles protected TOCNF hydrogels in their scaffold and prevented its degradation. On the other hand, rapid release activated by $\mathrm{pH}$ change followed zero-order kinetics, which is the preferred dynamics of all controlled release drug delivery mechanisms. By preparing very small hydrogel systems in polyHIPE particles resulting in high surface area to hydrogel volume ratio, complete release was achieved after only $30 \mathrm{~min}$. PolyHIPE/hydrogel systems are therefore potentially very useful systems in the field of targeted drug delivery, as hydrogel and polyHIPE morphology and/or chemistry can tailored to specific application. Last but not least, the non-toxicity of such systems also allows their use in the medical and pharmaceutical industries.

Author Contributions: Conceptualization, T.K. and A.P.; methodology, T.K., R.M., and A.L.; software, T.K. and A.R.; validation, T.K. and R.M.; formal analysis, T.K., R.M., and A.R.; investigation, T.K., R.M., and A.L.; resources, M.K. and A.P.; data curation, T.K. and A.R.; writing-original draft preparation, T.K., R.M., and A.L.; writing-review and editing, M.K., A.R., and A.P.; visualization, T.K. and A.P., supervision, A.P.; project administration, A.P.; funding acquisition, M.K. and A.P. All authors have read and agreed to the published version of the manuscript.

Funding: This research was funded by Slovenian Research Agency (ARRS) through projects J2-9440 and J7-2603 and programs P1-0153 and P2-0191.

Institutional Review Board Statement: Not applicable.

Informed Consent Statement: Not applicable.

Data Availability Statement: Not applicable.

Acknowledgments: The authors would like to thank Matejka Podlogar for SEM images.

Conflicts of Interest: The authors declare no conflict of interest.

\section{References}

1. Kutter, E.M.; Kuhl, S.J.; Abedon, S.T. Re-establishing a place for phage therapy in western medicine. Future Microbiol. 2015, 10, 685-688. [CrossRef]

2. Storms, Z.J.; Brown, T.; Cooper, D.G.; Sauvageau, D.; Leask, R.L. Impact of the cell life-cycle on bacteriophage T4 infection. FEMS Microbiol. Lett. 2014, 353, 63-68. [CrossRef]

3. Abedon, S.T. Use of phage therapy to treat long-standing, persistent, or chronic bacterial infections. Adv. Drug Deliv. Rev. 2019, 145, 18-39. [CrossRef]

4. Abedon, S.T.; Kuhl, S.J.; Blasdel, B.G.; Kutter, E.M. Phage treatment of human infections. Bacteriophage 2011, 1, 66-85. [CrossRef] [PubMed]

5. Górski, A.; Miedzybrodzki, R.; Weber-Dabrowska, B.; Fortuna, W.; Letkiewicz, S.; Rogóz, P.; Jończyk-Matysiak, E.; Dabrowska, K.; Majewska, J.; Borysowski, J. Phage therapy: Combating infections with potential for evolving from merely a treatment for complications to targeting diseases. Front. Microbiol. 2016, 7, 1-9. [CrossRef]

6. Lourenço, M.; De Sordi, L.; Debarbieux, L. The diversity of bacterial lifestyles hampers bacteriophage tenacity. Viruses 2018, 10, 327. [CrossRef] [PubMed]

7. Malik, D.J.; Sokolov, I.J.; Vinner, G.K.; Mancuso, F.; Cinquerrui, S.; Vladisavljevic, G.T.; Clokie, M.R.J.; Garton, N.J.; Stapley, A.G.F.; Kirpichnikova, A. Formulation, stabilisation and encapsulation of bacteriophage for phage therapy. Adv. Colloid Interface Sci. 2017, 249, 100-133. [CrossRef]

8. Guo, Z.; Lin, H.; Ji, X.; Yan, G.; Lei, L.; Han, W.; Gu, J.; Huang, J. Therapeutic applications of lytic phages in human medicine. Microb. Pathog. 2020, 142, 104048. [CrossRef]

9. Dabrowska, K. Phage therapy: What factors shape phage pharmacokinetics and bioavailability? Med. Res. Rev. 2019, 39, 2000-2025. [CrossRef] [PubMed]

10. Williams Smith, H.; Huggins, M.B. Effectiveness of phages in treating experimental Escherichia coli diarhoea in calves, piglets and lambs. J. Gen. Microbiol. 1983, 129, 2659-2675. [CrossRef]

11. Williams Smith, H.; Huggins, M.B.; Shaw, K.M. Factors influencing the survival and multiplication of bacteriophages in calves and in their environment. J. Gen. Microbiol. 1987, 133, 1127-1135. [CrossRef]

12. Jończyk, E.; Kłak, M.; Międzybrodzki, R.; Górski, A. The influence of external factors on bacteriophages-review. Folia Microbiol. 2011, 56, 191-200. [CrossRef] [PubMed]

13. Colom, J.; Cano-Sarabia, M.; Otero, J.; Cortés, P.; Maspoch, D.; Llagostera, M. Liposome-encapsulated bacteriophages for enhanced oral phage therapy against Salmonella spp. Appl. Environ. Microbiol. 2015, 81, 4841-4849. [CrossRef] [PubMed] 
14. Williams Smith, H.; Huggins, M.B. Successful treatment of experimental Escherichia coli infections in mice using phage: Its general superiority over antibiotics. J. Gen. Microbiol. 1982, 128, 307-318. [CrossRef]

15. Agarwal, R.; Johnson, C.T.; Imhoff, B.R.; Donlan, R.M.; McCarty, N.A.; García, A.J. Inhaled bacteriophage-loaded polymeric microparticles ameliorate acute lung infections. Nat. Biomed. Eng. 2018, 2, 841-849. [CrossRef] [PubMed]

16. Hornez, J.C.; Bouchart, F.; Meurice, E.; Descamps, M.; Leriche, A. Synthesis and fabrication of porous calcium phosphate ceramics for antibacterial bone substitutes. In Proceedings of the MATEC Web of Conferences, Villeneuve d'Ascq, France, 29-31 October 2013; Volume 7, pp. 10-12. [CrossRef]

17. Colom, J.; Cano-Sarabia, M.; Otero, J.; Aríñez-Soriano, J.; Cortés, P.; Maspoch, D.; Llagostera, M. Microencapsulation with alginate/CaCO 3: A strategy for improved phage therapy. Sci. Rep. 2017, 7, 1-10. [CrossRef]

18. Meireles Gouvêa Boggione, D.; Boggione Santos, I.J.; de Souza, S.M.; Santos Mendonça, R.C. Preparation of polyvinyl alcohol hydrogel containing bacteriophage and its evaluation for potential use in the healing of skin wounds. J. Drug Deliv. Sci. Technol. 2021, 63, 102484. [CrossRef]

19. Barros, J.A.R.; de Melo, L.D.R.; da Silva, R.A.R.; Ferraz, M.P.; de Rodrigues Azeredo, J.C.V.; de Carvalho Pinheiro, V.M.; Colaço, B.J.A.; Fernandes, M.H.R.; de Sousa Gomes, P.; Monteiro, F.J. Encapsulated bacteriophages in alginate-nanohydroxyapatite hydrogel as a novel delivery system to prevent orthopedic implant-associated infections. Nanomed. Nanotechnol. Biol. Med. 2020, 24, 102145. [CrossRef]

20. Bosio, V.E.; Islan, G.E.; Martínez, Y.E.; Castro, G.R. Control release applications in food technology. In Advances in Bioprocesses in Food Industries; Asiatech Press: New Delhi, India, 1900; Volume 1, pp. 1-13.

21. Meurice, E.; Rguiti, E.; Brutel, A.; Hornez, J.C.; Leriche, A.; Descamps, M.; Bouchart, F. New antibacterial microporous CaP materials loaded with phages for prophylactic treatment in bone surgery. J. Mater. Sci. Mater. Med. 2012, 23, 2445-2452. [CrossRef]

22. Trache, D.; Tarchoun, A.F.; Derradji, M.; Hamidon, T.S.; Masruchin, N.; Brosse, N.; Hussin, M.H. Nanocellulose: From Fundamentals to Advanced Applications. Front. Chem. 2020, 8, 392. [CrossRef]

23. Lin, N.; Dufresne, A. Nanocellulose in biomedicine: Current status and future prospect. Eur. Polym. J. 2014, 59, 302-325. [CrossRef]

24. Buwalda, S.J. Bio-based composite hydrogels for biomedical applications. Multifunct. Mater. 2020, 3, 022001. [CrossRef]

25. Zhou, J.; Yu, G.; Huang, F. Supramolecular chemotherapy based on host-guest molecular recognition: A novel strategy in the battle against cancer with a bright future. Chem. Soc. Rev. 2017, 46, 7021-7053. [CrossRef] [PubMed]

26. Zhou, J.; Rao, L.; Yu, G.; Cook, T.R.; Chen, X.; Huang, F. Supramolecular cancer nanotheranostics. Chem. Soc. Rev. 2021, 50, 2839-2891. [CrossRef] [PubMed]

27. Xu, H.; Liu, Y.; Xie, Y.; Zhu, E.; Shi, Z.; Yang, Q.; Xiong, C. Doubly cross-linked nanocellulose hydrogels with excellent mechanical properties. Cellulose 2019, 26, 8645-8654. [CrossRef]

28. Kopač, T.; Ručigaj, A.; Krajnc, M. The mutual effect of the crosslinker and biopolymer concentration on the desired hydrogel properties. Int. J. Biol. Macromol. 2020, 159, 557-569. [CrossRef]

29. Spaic, M.; Small, D.P.; Cook, J.R.; Wan, W. Characterization of anionic and cationic functionalized bacterial cellulose nanofibres for controlled release applications. Cellulose 2014, 21, 1529-1540. [CrossRef]

30. Kopač, T.; Krajnc, M.; Ručigaj, A. A mathematical model for pH-responsive ionically crosslinked TEMPO nanocellulose hydrogel design in drug delivery systems. Int. J. Biol. Macromol. 2021, 168, 695-707. [CrossRef]

31. Hariyadi, D.M.; Islam, N. Current status of alginate in drug delivery. Adv. Pharmacol. Pharm. Sci. 2020, 2020, 1-16. [CrossRef] [PubMed]

32. Šebenik, U.; Krajnc, M.; Alič, B.; Lapasin, R. Ageing of aqueous TEMPO-oxidized nanofibrillated cellulose dispersions: A rheological study. Cellulose 2019, 26, 917-931. [CrossRef]

33. Tang, Z.; Huang, X.; Baxi, S.; Chambers, J.R.; Sabour, P.M.; Wang, Q. Whey protein improves survival and release characteristics of bacteriophage Felix O1 encapsulated in alginate microspheres. Food Res. Int. 2013, 52, 460-466. [CrossRef]

34. Vinner, G.K.; Vladisavljević, G.T.; Clokie, M.R.J.; Malik, D.J. Microencapsulation of Clostridium difficile specific bacteriophages using microfluidic glass capillary devices for colon delivery using $\mathrm{pH}$ triggered release. PLoS ONE 2017, 12, 1-27. [CrossRef]

35. Gokmen, M.T.; Du Prez, F.E. Porous polymer particles-A comprehensive guide to synthesis, characterization, functionalization and applications. Prog. Polym. Sci. 2012, 37, 365-405. [CrossRef]

36. Desforges, A.; Arpontet, M.; Deleuze, H.; Mondain-Monval, O. Synthesis and functionalisation of polyHIPE®beads. React. Funct. Polym. 2002, 53, 183-192. [CrossRef]

37. Kramer, S.; Cameron, N.R.; Krajnc, P. Porous polymers from high internal phase emulsions as scaffolds for biological applications. Polymers 2021, 13, 1786. [CrossRef] [PubMed]

38. Huš, S.; Krajnc, P. PolyHIPEs from Methyl methacrylate: Hierarchically structured microcellular polymers with exceptional mechanical properties. Polymer 2014, 55, 4420-4424. [CrossRef]

39. Štefanec, D.; Krajnc, P. 4-Vinylbenzyl chloride based porous spherical polymer supports derived from water-in-oil-in-water emulsions. React. Funct. Polym. 2005, 65, 37-45. [CrossRef]

40. Gokmen, M.T.; Van Camp, W.; Colver, P.J.; Bon, S.A.F.; Du Prez, F.E. Fabrication of Porous "Clickable” Polymer Beads and Rods through Generation of High Internal Phase Emulsion (HIPE) Droplets in a Simple Microfluidic Device. Macromolecules 2009, 42, 9289-9294. [CrossRef] 
41. Lapierre, F.; Cameron, N.R.; Zhu, Y. Ready ... set, flow: Simple fabrication of microdroplet generators and their use in the synthesis of PolyHIPE microspheres. J. Micromech. Microeng. 2015, 25, 035011. [CrossRef]

42. Mert, E.H.; Yıldırım, H. Porous functional poly(unsaturated polyester-co-glycidyl methacrylate-co-divinylbenzene) polyHIPE beads through w/o/w multiple emulsions: Preparation, characterization and application. E-Polymers 2014, 14, 65-73. [CrossRef]

43. Lei, L.; Zhang, Q.; Shi, S.; Zhu, S. High internal phase emulsion with double emulsion morphology and their templated porous polymer systems. J. Colloid Interface Sci. 2016, 483, 232-240. [CrossRef] [PubMed]

44. Paterson, T.E.; Gigliobianco, G.; Sherborne, C.; Green, N.H.; Dugan, J.M.; MacNeil, S.; Reilly, G.C.; Claeyssens, F. Porous microspheres support mesenchymal progenitor cell ingrowth and stimulate angiogenesis. APL Bioeng. 2018, 2, 026103. [CrossRef] [PubMed]

45. Whitely, M.; Rodriguez-Rivera, G.; Waldron, C.; Mohiuddin, S.; Cereceres, S.; Sears, N.; Ray, N.; Cosgriff-Hernandez, E. Porous PolyHIPE microspheres for protein delivery from an injectable bone graft. Acta Biomater. 2019, 93, 169-179. [CrossRef]

46. Liu, L.; Yao, W.; Rao, Y.; Lu, X.; Gao, J. pH-Responsive carriers for oral drug delivery: Challenges and opportunities of current platforms. Drug Deliv. 2017, 24, 569-581. [CrossRef]

47. Sambrook, J.; Green, M.R. Molecular Cloning: A Laboratory Manual, 4th ed.; Cold Spring Harbor Laboratory Press: New York, NY, USA, 2012.

48. Mravljak, R.; Bizjak, O.; Podlogar, M.; Podgornik, A. Effect of polyHIPE porosity on its hydrodynamic properties. Polym. Test. 2021, 93, 106590. [CrossRef]

49. Vinet, L.; Zhedanov, A. Bacteriophages. In Methods in Molecular Biology; Clokie, M.R.J., Kropinski, A.M., Eds.; Humana Press: Totowa, NJ, USA, 2009; Volume 501, ISBN 978-1-58829-682-5.

50. Ritger, P.L.; Peppas, N.A. A simple equation for description of solute release I. Fickian and non-fickian release from non-swellable devices in the form of slabs, spheres, cylinders or discs. J. Control. Release 1987, 5, 23-36. [CrossRef]

51. Ritger, P.L.; Peppas, N.A. A simple equation for description of solute release II. Fickian and anomalous release from swellable devices. J. Control. Release 1987, 5, 37-42. [CrossRef]

52. Guo, X.; Rong, Z.; Ying, X. Calculation of hydrophile-lipophile balance for polyethoxylated surfactants by group contribution method. J. Colloid Interface Sci. 2006, 298, 441-450. [CrossRef]

53. Stroud, R.M.; Serwer, P.; Ross, M.J. Assembly of bacteriophage T7. Dimensions of the bacteriophage and its capsids. Biophys. J. 1981, 36, 743-757. [CrossRef]

54. Camilleri, M.; Colemont, L.J.; Phillips, S.F.; Brown, M.L.; Thomforde, G.M.; Chapman, N.; Zinsmeister, A.R. Human gastric emptying and colonic filling of solids characterized by a new method. Am. J. Physiol. Gastrointest. Liver Physiol. 1989, 257, G284-G290. [CrossRef]

55. Yang, X.; Li, Z.; Liu, H.; Ma, L.; Huang, X.; Cai, Z.; Xu, X.; Shang, S.; Song, Z. Cellulose-based polymeric emulsifier stabilized poly(N-vinylcaprolactam) hydrogel with temperature and pH responsiveness. Int. J. Biol. Macromol. 2020, 143, 190-199. [CrossRef]

56. Shi, X.; Zheng, Y.; Wang, G.; Lin, Q.; Fan, J. pH- and electro-response characteristics of bacterial cellulose nanofiber/sodium alginate hybrid hydrogels for dual controlled drug delivery. RSC Adv. 2014, 4, 47056-47065. [CrossRef]

57. Kumar, S.; Singh, A.K.; Prajapati, S.K.; Singh, V.K. Formulation and Evaluation of once daily sustained release matrix tablets of Aceclofenac using natural gums. J. Drug Deliv. Ther. 2012, 2. [CrossRef]

58. Sutton, S. Microbiology topics. Accuracy of plate counts. J. Valid Technol. 2011, 17, 42-46.

59. Sutton, S. The limitations of CFU: Compliance to CGMP requires good science. J. GXP Compliance 2012, 16, 74-80.

60. Setapa, A.; Ahmad, N.; Mahali, S.M.; Amin, M.C.I.M. Mathematical model for estimating parameters of swelling drug delivery devices in a two-phase release. Polymers 2020, 12, 2921. [CrossRef] [PubMed]

61. Kim, H.Y.; Chang, R.Y.K.; Morales, S.; Chan, H.K. Bacteriophage-delivering hydrogels: Current progress in combating antibiotic resistant bacterial infection. Antibiotics 2021, 10, 130. [CrossRef]

62. Laracuente, M.-L.; Yu, M.H.; McHugh, K.J. Zero-order drug delivery: State of the art and future prospects. J. Control. Release 2020, 327, 834-856. [CrossRef] 